\title{
FIP1L1/PDGFRA Fusion Gene
}

National Cancer Institute

\section{Source}

National Cancer Institute. FIP1L1/PDGFRA Fusion Gene. NCI Thesaurus. Code C99743.

A fusion gene $(\sim 2.6 \mathrm{~kb})$ that results from a chromosomal deletion del(4)(q12q12) which fuses the 5' half of the FIP1L1 gene to the 3' part of the PDGFRA gene. This rearrangement is associated with myeloproliferative disorders. 